ALONE IN SCI-FI:

THE IMPOSSBILITY OF ONENESS

IN BLADE RUNNER 2049

AND EMPIRE OF THE SENSELESS

Yasmina Jaksic 


\title{
ALONE IN SCI-FI: THE IMPOSSBILITY OF ONENESS IN BLADE RUNNER 2049 AND EMPIRE OF THE SENSELESS
}

Yasmina Jaksic

\author{
When we put our central nervous system outside us, \\ We returned to the primal nomadic state. \\ - Marshall McLuhan, Book of Probes \\ The new media are not bridges between man and nature, \\ they are nature. \\ - Marshall McLuhan, Book of Probes
}

As McLuhan prophesized, the new mediums of electric and communicative technology are no longer separate from the human body and have become rather an extension of body and a reflection of contemporary overloaded minds. Anxieties about technological autonomy steadily increase as artificial intelligences strive towards singularity as the boundaries between human and nonhuman become increasingly indistinguishable. Technological singularity occurs at the moment artificial intelligence surpasses human capacity and thus can theoretically obtain self-sovereignty and execute power over others. Interestingly though, in Denis Villeneuve's Blade Runner 2049 (2017) and Kathy Acker's Empire of the Senseless (1988), works created nearly 30 years apart, it is not the fear of technological singularity that fuels the narratives, but rather a persistent fear of insurmountable governmental power - utilizing technology to come into direct and unmediated contact with life - which shatters attempts at community building.

Foucault's notion of biopower - where modern society executes power over the body in the name of "life" is complicated by both works which present a future in which power confronts not only biological life, but "alternative" lives that occupy the interval between human and machine, and live within a society overtly seeking to negate any claim to bodily autonomy and agency, retrieving the histories of racialized, gendered, and sexuality-driven subjugation society rests on. Blade Runner 2049 and Empire of the Senseless anticipate what these hybridized beings might look like through the replicants of Blade Runner and the cyborgs of Empire. In conjunction with Foucault, Hardt and Negri theorize a postmodern sovereignty where the source of domination becomes unclear. Instead, under the "supranational sovereignty of the Empire" power is dispersed "horizontally according to the model of a rhizomatic network." 
The rhizomatic structure borrowed from Deleuze and Guattari has been flipped by Hardt and Negri to reveal its darker undercurrent. Deleuze and Guattari initially posited the rhizome as a network structure that can "send up new growths anywhere along their length, not subject to centralized control or structure" with the rhizome promoting new modes of thinking that "grows between things and produces offshoots in unforeseen directions." Blade Runner 2049 and Empire of the Senseless oscillate between these two uses of rhizomatic structures. In both narratives, the threat of widespread power, now under the guise technology provides, is surfaced from its subliminal camouflage, but an implicitly political narrative persists - one that underscores multiplicity and, in Deleuze and Guattari's terms, lines of flight that branch off from oppressive power structures to provide alternate ways of being and being together.

Blade Runner 2049 introduces K, a Nexus 9 replicant and blade runner. As K navigates the landscape of a future Los Angeles in the introductory scenes, the height of the city remains uniform until he reaches the LAPD building at the city's core: the tallest and widest structure seen. By taking up the most physical space in the shot, consuming K's ship in comparison, the LAPD structure is established as a location of immense power. K's boss Joshi has just learned, alongside K, of a replicant-born child. In immediate panic, she tells $\mathrm{K}$ that it is their job to "keep order," order here extending now to the ordering of life and death. ${ }^{3}$ Joshi orders $\mathrm{K}$ to annihilate the child: "This breaks the world, K." 4 The child, woman-born instead of man-made, ruptures the power relation between human and replicant: they no longer rely on man for life, and thus move towards self-emancipation and self-sovereignty.

The politics of power remain prominent throughout the film. $\mathrm{K}$ is referred to by the derogatory terms "skinner," and "skinjob," having his apartment door defaced and co-workers ostracize him, echoing histories of racist and homophobic violence. Upon the discovery of Rachael's remains, a replicant from the original Blade Runner, the lab worker dismisses her death as "another skin job...maybe [another replicant] ate it," refusing to refer to her as subject rather than object. Replicants are dehumanized, associated with acts of savagery, rendering them nonbeings. Dr. Ana Stelline muses: "Replicants live such hard lives, made to do what we'd rather not." ${ }^{6}$ Replicants are thus made to be the "shadow" of humans - their dark counterparts who engage in murder and slave labour, whom humans offload all of their societal taboos onto, not unlike the histories of slavery and colonial control.

As Payne and Pitsis note, Blade Runner 2049 makes extensive use of Vladimir Nabokov's Pale Fire, in particular Nabokov's attention to environment and illusion. They point to Nabokov's "Canto One": "I was the shadow of the waxwing slain / By the false azure in the windowpane."7 Nabokov plays with a string of associations here: the speaker is not the bird but a "shadow" of the bird, like the replicant to the human, and the window is not the sky but a false illusion, trapping the bird but perhaps not its shadow. Blade Runner 2049 surfaces the subliminal "dispersing" of power that has become a part of the modern environment, that provides the illusion of endless skies when instead they present only the window of glass screens. As Nabokov writes, "we are most artistically caged." The camouflages of contemporary power structures have become increasingly "artistic" - providing the illusion of self-governance and power, when the reality lacks depth and further isolates, imprisons, and encloses one from engaging in building a community.

\footnotetext{
2 Gilles Deleuze and Felix Guattari, "'Introduction: Rhizome' in A Thousand Plateaus: Capitalism and Schizophrenia” in The Norton Anthology of Theory and Criticism (New York: W.W. Norton \& Company, 2001), 22.

3 Denis Villeneuve, dir. Blade Runner 2049 (2017; Burbank, CA Warner Bros Pictures, 2019. Netflix), 28:20.

Ibid, 28:20.

Ibid, 27:12.

Ibid, 1:18:52.

Catherine Payne and Alexandra Pitsis, "On Nature and the Tactility of the Senses in Blade Runner 2049." Journal of Asia-Pacific Pop Culture vol. 3 no. 1, (2018): 55.
} 
A competing force of power, "Wallace Corporations", likewise takes up insurmountable space on the screen. ${ }^{8}$ Inside, the lighting is warm, with light rippling across the perfectly symmetrical walls like water. The series of perfect prisms evokes ancient structures of worship, of life and death. Walls and floors are clad in a clay-like colour and texture, with narrow passageways. ${ }^{9}$ From the ceiling, a skylight drops a replicant body through a transparent tube: a womb. ${ }^{10}$ Wallace and his replicants compete with Joshi and the LAPD in the ultimate race for complete power, symbolized through the pitting of Joshi against Wallace's most beloved replicant, Luv: "You tiny thing. In the face of the fabulous new, your only thought is to kill it? For fear of great change? You can't hold the tide back with a broom." ${ }^{11}$ Luv herself is caged and blindsided by Wallace's "love" for her, however. Wallace's claim to the reproductive rights of the replicants is no different from the humans, fronted by Joshi and the LAPD: both parties of power manipulate the bodies of replicants for differing agendas - the humans for social control, class subjugation, slave labour, and Wallace for capital gain and the acquisition of centralized power.

When $\mathrm{K}$ is first introduced in the film, he is in the process of completing a 'retirement', a euphemism for murder. K kills Sapper Morton, who was involved in the Blackout-an attack that destroyed the country's electronic records, its memory. Memory plays a key role in both Blade Runner and Empire of the Senseless as a source of identity, history, and thus, agency. When memories are uploaded into cyberspace, they are no longer the sole property of the individual and thus the individual is subject to inescapable surveillance. Foucault's concept of panoptic surveillance (where one is constantly "seen" and acts accordingly) is further complicated in the context of cloud technology which can be (and is) infiltrated by government surveillance and individual spying, despite the promise of protection. Technology impedes further and further into human interiority and thus subjects both humans and their "artificial" counterparts to perpetual surveillance. In both works, entire consciousnesses, and entire holographic beings (like Blade Runner 2049's Joi), can be uploaded, hosted, and stored. Thus, in both works, the attack on the city's memories instead of symbolic physical structures, such as the LAPD, is significant in its crippling of centralized powers by denying them access to the consciousnesses of individuals.

In Acker's Empire, Thivai, a self-proclaimed pirate, and Abhor, "part robot part black,"12 is employed by Schreber to attack the CIA library as "the library was the American Intelligence's central control network, its memory, what constituted its perception and understanding." ${ }^{13}$ Acker flips Artificial Intelligence (Al) to American Intelligence, underscoring anxieties not of technological singularity but the acquisition and growth of existing centralized power structures, supra-nations like the United States, through technological invasion of individual consciousness. By annihilating American Intelligence's "memory," Thivai and Abhor attempt to rupture national identity, to pave the way for new modes of being. Acker articulates the integral interconnectivity of memory and identity: "By having no memory, I couldn't recognize myself" Abhor states. ${ }^{14}$ The annihilation of memory gestures towards an eternal present, with the self never fixed to "constructs" but always in processes of "becoming" without restrictions, a subject in constant unrestrained flux, as Deleuze and Guattari posit as a possibility in rhizomatic networks. Abhor is particularly interested in the obsolescence of memory as a function of power structures. By wiping her own memory, she is able to ascribe herself with the agency her childhood had largely denied her and unlearns patterns of passive behaviour. Abhor is a cyborg, described by Donna Haraway as a hybrid of machine and organism, a boundary creature that by its very nature does not "participate in the various traditional mythologies that have defined the West." ${ }^{15}$ Essential to these myths is the question of identity, which the cyborg interrupts

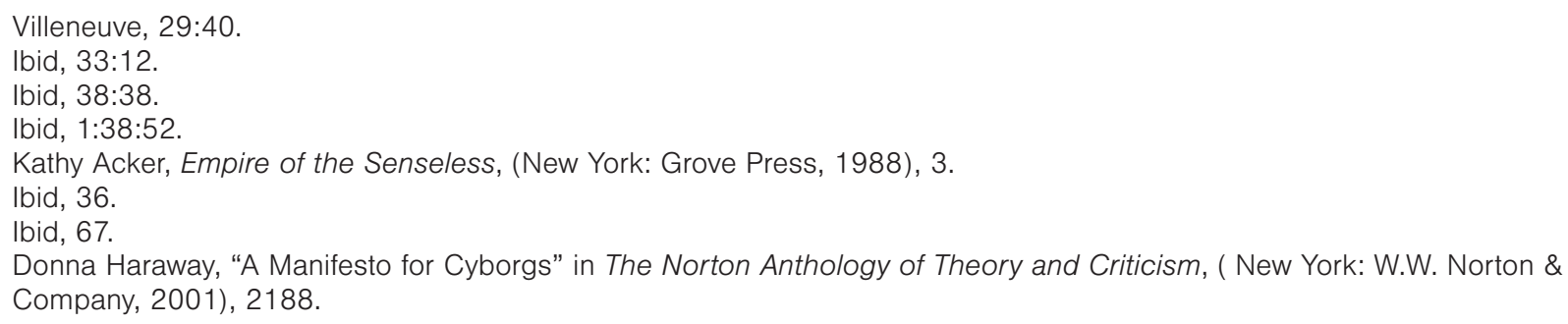


by having no "origin story," rewriting the nightmare of the "awful apocalyptic telos of a self united at last from all dependency, a man in space," a Western nightmare of dislocation, into a narrative of self-emancipation. ${ }^{16}$ Haraway claims that for cyborgs "fathers are inessential." ${ }^{17}$ However, for Abhor, the father is very much present, and "cyberspace" does not provide her the opportunity to escape her material confines of her racial or gender identity.

Abhor describes the abuse she experiences living with her father. In a Plath-like movement, Abhor refers to her dysfunctional father as both Daddy and Doctor, pillars of patriarchal power over the female subject. "Daddy played all sorts of games with me...He trained me into total physical perfection...He showed me how to insert a razor blade into my wrist just for fun...Daddy left me no possibility of easiness. He forced me to live among nerves sharper than razor blades, to have no certainties. There was only roaming." 18 Abhor's childhood of exposure to extreme violence, like those who have been exposed to violence in reality or through media, forces her consciousness and identity to develop around fear and proximity to death. Abhor is exposed, like a raw nerve, and thus becomes hyper-aware of the subliminal structures seeking to deny her any claim to her own body, ones that she feels only she is able to perceive. Like McLuhan theorized, in both narratives of a technologically enhanced future, the characters are left to "wander", for access to their identities has been uploaded and lost in the cybernetic webs of power.

Acker complicates Abhor's abuse further through Abhor's awareness of her status as both victim and accomplice: "part of me wanted him and part of me wanted to kill him." 19 Abhor's origins are increasingly convoluted: her mother is not her real mother, her father is perhaps not her real father, and in another flip, her father becomes her boss and her doctor, Dr. Schreber. Likewise, reality is further muddied and whether or not the events of the novel take place in material reality or cyberspace remains entirely unclear. Abhor posits that reality is controlled by the unknown forces of power and their weaponization of technology and biopower:

The multinationals along with their computers have changed and are changing reality. Viewed as organisms, they've attained immortality via bio-chips... Who needs slaves anymore? So killing someone, anyone, like Reagan or the top IBM executive board members, whoever they are, can't accomplish anything," I blabbed, and I wondered if there was only despair and nihilism. ${ }^{20}$

Abhor exposes the intricacy of networks of power that cannot be annihilated by attacking the head "figures" that pervade public consciousness. It is the subliminal structures, buried in the "computers" that "change reality," that Abhor attempts to wage war with but cannot so easily be discerned. Her journey for justice and identity leaves her "losing" herself "in the desert" of Paris, wondering if her mission is pointless in the face of the insurmountable power of which she has become aware.

Acker's project, explored through Abhor, is challenging the totality of knowledge through subjugated knowledges (Foucault) by the introduction of the "taboo," which has been disqualified from discourse, into dominant language:

Nonsense would attack the empire-making (empirical) empire of language, the prisons of meaning...What is the language of the 'unconscious'? (If this ideal unconscious or freedom doesn't exist: pretend it does, use fiction, for the sake of survival, all of our survival.) Its primary language must be taboo, all that is forbidden. Thus, an attack on the situation of prison via language would demand the use of a language or languages which aren't acceptable, which are forbidden. Language, on one level, constitutes a set of codes and social and historical agreements. ${ }^{21}$ 
Acker's use of "codes" carries double resonance in the text - social codes and technological codes. To "hack" and infiltrate the "prisons" created in corporeality and cyberspace with nonsense is to flood the systems with unfiltered, "organic" utterances (Kristevian semiotic urges) that cannot be structured and thus weaponized against the individual - only nonsense can interrupt and corrupt the codes. Furthermore, Abhor's narration of the reality of child rape and the reclamation of the word "cunt" forces that which has been rendered "nonsense," that which has been rejected by dominant narratives, into the system in order to destroy what has been glossed over (fetishization of the young, innocent female, weaponization of language against women) and normalized in mainstream media.

In a similar gesture, Blade Runner 2049 examines multiplicity on the level of language and narrative. When $\mathrm{K}$ takes his first baseline test of the movie, he joins in a collaborative reciting of Pale Fire with the interrogator:

$\mathrm{K}$ : And blood-back nothingness began to spin A system of cells interlinked within cells, Interlinked within cells, Interlinked within one stem, And dreadfully distinct, Against the dark, A tall white fountain played. Man: Cells.

$\mathrm{K}$ : Cells.

Man: Have you ever been in an institution?

Man: Cells.

$\mathrm{K}$ : Cells.

Man: Do they keep you in a cell?

Man: Cells.

$\mathrm{K}$ : Cells.

Man: What's it like to hold the hand of someone you love?

Man: Interlinked.

$\mathrm{K}$ : Interlinked.

Man: What's it like to hold your child in your arms?

Man: Interlinked.

K: Interlinked. ${ }^{22}$

Unlike in the previous Blade Runner, the baseline testing here appears to be testing for a lack of empathy, a lack of desire to be interlinked. The scene features a close-up shot of the back of K's head. His voice and the interrogator's voice are accompanied by a frantic ringing in the room. When $\mathrm{K}$ completes the test, the interrogator calls him "constant K." K now sits centre screen, expressionless. If K does not fear confinement, if he does not desire connection, he can function as the Nexus 9 blade runner he was designed to be. $\mathrm{K}$ and the other replicants must continually be "put in their place" through this process - they are a cog in the machine, not an individual part of a family or community.

When $\mathrm{K}$ takes the test for the second time, he fails. $\mathrm{K}$ has discovered a reason to live, a journey for identity, based on a memory. K envisions that he's interlinked - he has parents, he could be a parent. K now recites Nabokov with the intended affect provoked by the words. K himself attempts to conceal the poem's resonance, reciting in the same monotonous manner he had previously, but the close-ups of his eyes are now shown. K's eyes are intense and unblinking, and slight hesitation is present in his answers. When the test is over, $\mathrm{K}$ can be seen trembling slightly and swallowing hard again. Joshi says, "Scan says you didn't look like you on the inside." ${ }^{23}$ K's very cells have been rearranged; he has been transformed. He believes himself to be the miracle child, "of woman born," as Joi says, "wanted. Loved." 24 The quest for the miracle child has become a quest for K's identity.

22 Villeneuve, 14:25.

23 Ibid, 1:24:33

24 Ibid, 57:10. 
The male quest for identity is flipped, however, in both Blade Runner 2049 and Empire of the Senseless. Dr. Ana Stelline is instead the real-born daughter of Rachael and Deckard. Ana is acclaimed for her "authentic" memories, "Wallace needs my talent for a stable product," she explains. ${ }^{25}$ To create memories is viewed as a human action, one that, as Ana claims, creates "real human responses." ${ }^{26}$ Ana herself complicates this idea with her status as replicant-born, ironic due to the emotional intensity with which she can "create" memories: "They think it's all about detail, but that's not how memory works. We recall with our feelings. Anything real should be a mess." ${ }^{27}$ Ana's model of memory is rhizomatic. It does not recall with the accuracy and detail as computer memory can, with total recall, it relies on emotions and feelings, fragments and sensations. For replicants to experience memory is to experience the incompleteness of humanity.

With Ana as the miracle child, the power of the rebellion is coded female in the ability to give birth, to create multiplicities. "I know that baby meant that we are more than just slaves...She will lead our army," Freysa, the resistance leader proclaims. ${ }^{28} \mathrm{~A}$ new cell has formed, one of rebellion. The coding of the resistance of symbolic order as female retrieves Julia Kristeva's theory of the semiotic and symbolic. For Kristeva ${ }^{29}$ there is an interval between the semiotic (pre-language, pre-Oedipal) unstructured urges and the symbolic (rule-bound, social order). In order to rewrite into phallogocentric discourse a possibility of articulating female or alternative experience, Kristeva returns to the maternal womb as a space of protolinguistic language that is tied to the corporeal, a language of the body, not yet translated or mistranslated into discourse.

Acker's text flips the male hero quest instead, by giving voice, and thus ownership of one's narrative, to the "silent cybergirl" through Abhor. Thivai gives Abhor a pen because he wants her to "write down her memoirs," clarifying that he wants her to "write down, with her own blood as ink, how we rescued her, how brave our hearts were, how strong our arms." ${ }^{30}$ Yet Abhor does not know how to write because, Thivai says, "being black, she was uneducated." 31 Thivai teaches her, claiming "to write is to reveal a heart's identity," ${ }^{32}$ and thus Abhor prints out her first words: "FUCKFACES ALL MEN / THE SHIP IS SINKING." 33 Abhor rejects the narrative Thivai tries to feed her and writes her own truth. Abhor refuses the narrative of male heroism and breaks through the subjugation she faces: "the ship is sinking" signals an apocalypse - destruction in favour of rebirth. On one of the letters they send, a scroll is drawn with the writing "IN MEMORY OF VLADIMIR," another gesture towards Nabokov, who provides the grounds for rhizomatic multiplicities that evade linear, phallogocentric discourses.

Joi, K's pocket cybergirl in Blade Runner is, like Abhor, racialized. A customization menu appears when K operates her, with the screen displaying the physical makeup of Joi: "Body type: Slim / Face type: Oval / Skin tone: Olive / Hair: Brown / Ethnicity: Cuban." ${ }^{34}$ To emphasize Joi's ethnicity is an interesting directorial choice, gesturing towards a more optimistic rendering of a rhizomatic structure in which diverse groups of peoples can wield and share power. This structure is further emphasized by the female-led resistance, but would have been strengthened had Joi played a larger role in the acquisition of autonomy for both herself and K. Joi's subjectivity in the film is questionable as she appears as no more than an extension of K's consciousness and his fantasies. She does not articulate her own experience and never speaks of herself - the only time she speaks "for" herself is when she declares her love for K.

Villeneuve, 1:18:52

Ibid.

Villeneuve, 1:20:15

Ibid, 2:04:55-2:07:16

Julia Kristeva, "Part 1, The Semiotic and the Symbolic" in The Norton Anthology of Theory and Criticism, (New York: W.W. Norton \& Company, 2001).

Acker, 201.

Ibid.

Ibid, 204

Ibid.

Villeneuve, 19:56. 
Joi first appears dressed in a 1950's housewife costume, with a bouffant hairstyle, a poodle skirt and apron. ${ }^{35}$ The advertisement for Joi that acts as a refrain throughout the film echoes, "Joi goes anywhere you want her to go." ${ }^{36} \mathrm{Joi}$ is completely malleable - she is anything $\mathrm{K}$ wants her to be, she can go anywhere $\mathrm{K}$ wants her to go. Joi's image frequently glitches out and all the light around her shines through her transparent figure, and similarly, she is the vessel through which K's innermost desires shine through. Joi weaves in and out of $\mathrm{K}$ as he studies the records for traces of the miracle child. "I always knew you were special," she says to him partially inside of his body, acting as his inner voice projected outward, manifested in a cybergirl. ${ }^{37} \mathrm{Joi}$ is a phantasm - $\mathrm{K}$ cannot touch her until Joi recruits Mariette, a replicant posing as a sex worker. The two women morph into one another, becoming "one," while doubled ${ }^{38}$ - two sets of hands grope at K's head actualizing male-constructed fantasies of multiple subservient females and executing the male gaze through the characterization of "transparent" and spectral female bodies.

Thivai, Abhor's male lover, similarly attempts to control Abhor's movement. He writes a letter to the CIA in order to have her imprisoned upon Abhor's proclamation of love for another woman. By controlling her movement, Thivai feels he has regained power over her: "I figured if they put Abhor, in prison I'Id [sic] be able to see her everyday." ${ }^{39}$ In Thivai's letter "Dear CIA," he calls Abhor the "runaway nigger" recalling the language of antebellum America. ${ }^{40}$ By coding Abhor a slave, Thivai is both executing his ownership over her while simultaneously addressing, like Blade Runner, the subjugation of cyborg/ replicant beings in these future worlds. Abhor's name itself retrieves "abhorrent," as inspiring repugnancy, and furthermore Shakespeare's Caliban, referred to by Miranda as the "abhorred slave." Abhor shines light through the abhorrent, she wields language, like Caliban: "You taught me language, and my profit on " $t$ / Is I know how to curse" (I. II). In her own letter, Abhor comes to the conclusion that "the whole world is men's bloody fantasies" 41 and decides to "be a part of a motorcycle gang." 42 Thivai cannot perceive the confines that still suppress Abhor, "If you're free, Abhor, why do you bother protesting?" 43 In a gesture towards liberation, Abhor de-programs herself, living now without any code. "I'm the piercer and the pierced" she declares, emphasizing her awareness and acceptance of herself as victim and accomplice. ${ }^{44}$ "And then I thought that, one day, maybe, there'ld be a human society in a world which is beautiful, a society which wasn't just disgust." ${ }^{45}$ In Abhor's final words, she envisions a positive futurity, making use of an invented tense "there'ld," evoking both "there would be" and "there will be" combining and layering a possible future with a factual declaration. Acker's final disruption of language posits a conditional future and a tension: there "would be" a beautiful future and there "will be," ending the novel by maintaining its dislocation and uncertainty. However, the possibility for change is not eliminated.

Likewise, by the end of the Blade Runner 2049, hope persists in the replicant-born child, a symbol of reproductive futurity, liberation, and resistance. Dressed in all-white, Ana is anything but a shadow. She is the light that breaks through the glass dome she has been condemned to, and the glass that shrouds the world of 2049. Deckard's hand against the glass brings into awareness the invisible imprisonment power structures can execute through technological invasion of internal, personal memories, histories, and identities. In both Empire of the Senseless and Blade Runner 2049, the multiplicity and dissemination of power is combatted through a disruption of power from within: multiple lines of flight departing from structures of power, building communities of rhizomatic networks that resist hierarchy and subjugation. Both texts conclude with the possibility of hope through a violent rage against the symbolic, and thus the inert, at the level of language and at the level of institution. 


\section{BIBLIOGRAPHY}

Acker, Kathy. Empire of the Senseless. New York: Grove Press, 1988.

de Zwaan, Victoria. "Rethinking the Slipstream: Kathy Acker Reads 'Neuromancer.'" Science Fiction Studies 24, no. 3 (1997): 459-470. www.jstor.org/stable/4240647.

Foucault, Michel. The History of Sexuality Vol 1. New York: Vintage, 1976.

Deleuze, Gilles and Felix Guattari. “'Introduction: Rhizome' in A Thousand Plateaus: Capitalism and Schizophrenia" in The Norton Anthology of Theory and Criticism. New York: W.W. Norton \& Company, 2001.

Haraway, Donna. "A Manifesto for Cyborgs" in The Norton Anthology of Theory and Criticism. New York: W.W. Norton \& Company, 2001.

Hardt, Michael and Antonio Negi. "Empire" in The Norton Anthology of Theory and Criticism. New York: W.W. Norton \& Company, 2001.

Kristeva, Julia. "Revolution in Poetic Language, 'Part 1, The Semiotic and the Symbolic'" in The Norton Anthology of Theory and Criticism. New York: W.W. Norton \& Company, 2001.

McLuhan, Marshall. The Book of Probes. Berkeley: Gingko Press, 2003.
Payne, Catherine and Alexandra Pitsis. "On Nature and the Tactility of the Senses in Blade Runner 2049." Journal of Asia-Pacific Pop Culture 3 no. 1, (2018): 55-74. muse.jhu.edu/article/701300.

Villeneuve, Denis, dir. Blade Runner 2049. 2017; Burbank, CA Warner Bros Pictures, 2019. Netflix. 